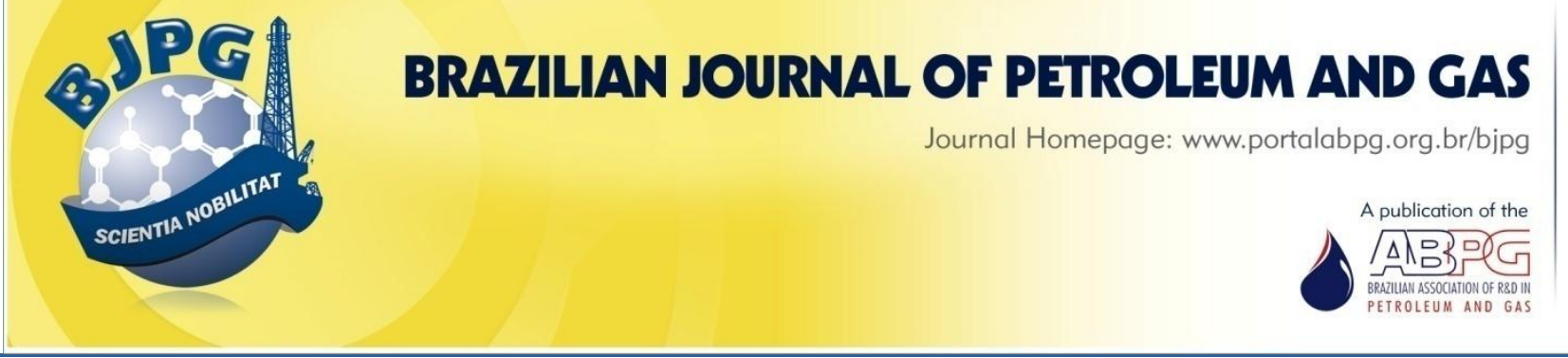

\title{
INHIBITION OF MICROBIAL SULFATE REDUCTION BY MOLYBDATE
}

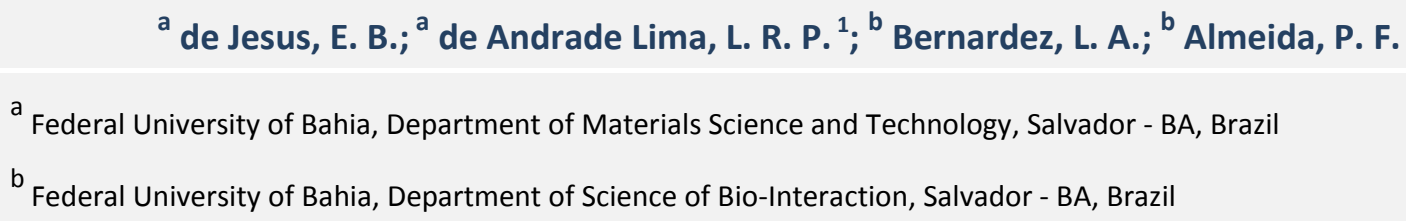

\begin{abstract}
Hydrogen sulfide generation in oil production is a constant cause of concern. In several cases this phenomenon occurs due to the action of sulfate-reducing bacteria. Various methods, including biocides and nitrate addition, have been used to control the activity of these microorganisms, but they are expensive and have side effects. Other inhibition methods, such as the use of molybdate, have received much less attention. This study performed a kinetic test for the inhibition of sulfate reduction, and shortterm tests to determine the minimum inhibitory concentration of molybdate in liquid medium containing 10.4 and $20.8 \mathrm{mM}$ of sulfate $\left(1000 \mathrm{mg} \mathrm{L}^{-1}\right.$ and $\left.2000 \mathrm{mg} \mathrm{L}^{-1}\right)$, respectively. An inoculum was prepared from a microbial consortium of sulfate-reducing bacteria dominated by Desulfovibrio vulgaris enriched from produced water from oil wells of the Reconcavo Basin, Brazil. The indicators of bacterial activity used were: sulfate reduction, sulfide production, culture medium color, $\mathrm{pH}$, and redox potential. The tests show that, regardless of the concentration of molybdate, sulfate reduction is inhibited after the first hours of the start of the test. The conversion of sulfate in the kinetic experiment without molybdate is $78 \%$, whereas the average conversion in the experiment with molybdate is approximately $30 \%$ in $216 \mathrm{~h}$. The short-term test results show that $0.08 \mathrm{mM}\left(12.8 \mathrm{mg} \mathrm{L}^{-1}\right)$ molybdate, a molar ratio molybdate/sulfate of 0.004 , is sufficient to inhibit the activity of sulfate-reducing bacteria for $168 \mathrm{~h}$.
\end{abstract}

\section{KEYWORDS}

souring; sulfate-reducing bacteria; kinetics; inhibition

\footnotetext{
${ }^{1}$ To whom all correspondence should be addressed.

Address: Federal University of Bahia, C. P. 6974, Salvador - BA, Brazil.

ZIP Code: 41810-971 | Phone: +55(71)3283-9514 |e-mail: lelo@ufba.br

doi:10.5419/bjpg2015-0010
} 


\section{INTRODUCTION}

The generation of hydrogen sulfide in oil production is a matter of concern due to the risk of anaerobic corrosion of pipelines and steel structures. This corrosion clogs pipelines posing an occupational and environmental hazard due to the contamination of fuels. The primary generation, due to thermochemical reduction of sulfate, may cause the accumulation of hydrogen sulfide in oil fields. The secondary generation, due to the action of sulfate-reducing bacteria (SRB), may take place during oil recovery using water injection. The use of inhibitors, such as nitrate and molybdate ions, to reduce metabolic activity has been investigated in a few laboratories and field experiments (Sunders \& Sturman, 2005).

Sulfate-reducing bacteria are microorganisms that survive in anoxic environments with a $\mathrm{pH}$ in the range of 5 to 9 , and reducing sulfate to sulfide by transferring electrons obtained by the oxidation of a carbon source. Species within the genus Desulfovibrio have been used mostly as model organisms for investigating the mechanism of sulfate reduction (Birkeland, 2005). These species partially oxidize volatile fatty acids turning them into acetate and $\mathrm{CO}_{2}$, according to the following equation (Sunders \& Sturman, 2005):

$$
\begin{aligned}
& 2 \mathrm{CH}_{3} \mathrm{CHOHCOO}^{-}+\mathrm{SO}_{4}^{2-} \underset{\mathrm{SRE}}{\longrightarrow} 2 \mathrm{CH}_{3} \mathrm{COO}^{-}+ \\
& +2 \mathrm{CO}_{2}+2 \mathrm{H}_{2} \mathrm{O}+\mathrm{S}^{2-}
\end{aligned}
$$

Equation 1 shows that, for each mole of sulfate reduced, two moles of the carbon source are required and one mole of sulfide is generated. Depending on the $\mathrm{pH}$ of the solution, the sulfide generated can remain as $\mathrm{S}^{2-}, \mathrm{HS}^{-}$to $\mathrm{H}_{2} \mathrm{~S}$ (Bernardez et al., 2012, 2013).

The problems caused by the presence of SRB in reservoirs and oil production systems have motivated the development of methods to control and prevent the action of these microorganisms. Among these methods one can highlight: i) the use of a chemical scavenger for the removal of sulfide production; ii) the use of non-metallic pipes or pipes lined with materials resistant to the presence of hydrogen sulfide; iii) the use of corrosion inhibitors; (Larsen et al., 2004); iv) the selection of the source of injection water with low sulfate concentration, volatile fatty acids, nutrients and biomass; v) the removal of the sulfate present in the injection water using reverse osmosis or nanofiltration membrane; (Rizk et al., 1998; Jordan \& Walsh, 2004; Robinson et al., 2010); vi) the control of oxygen levels in the injection water, (Chang et al., 2007); and vii) the control of microbial activity through the use of biocides (Larsen et al., 2000; Maxwell et al., 2002).

The control of SRBs using alternative methods based on the application of inhibitors of inorganic origin, such as nitrate ions, has received considerable attention (Jenneman et al., 1986; Davidova et al., 2001; Myhr et al., 2002; Greene et al., 2003; Kaster et al., 2007). Nitrate ions act by stimulating the growth of native microorganisms that: i) compete with the SRB for the available carbon source in the medium; ii) oxidize biologically the sulfides generated from the SRB; and iii) produce intermediates, such as nitrite, which increases the redox potential (Hubert et al. 2005). In addition, some SRBs are capable of reducing nitrate instead of sulfate. Although the treatment with nitrate acidification is effective in laboratory studies and in some field tests, this treatment does not remove the biomass accumulation in the pores of the reservoir rock and, thus, does not prevent the clogging of injection wells and production. In addition, some authors have questioned the effectiveness of using nitrate biocorrosion control suggesting that, under certain conditions, the corrosion rate increases (Hubert et al., 2005; Rempel et al., 2006).

Molybdenum is an essential chemical element for biological systems, including the anaerobic sulfate-reducing bacteria (Biswas et al., 2009). It is used by these microorganisms in the synthesis of enzymes responsible for catalyzing reduction reactions, and it plays a key role in nitrogen, carbon, and sulfur cycles (Barajas et al., 2011). However, an environment with high concentrations of this element is unsuitable for the development of microorganisms (Biswas et al., 2009). The molybdate ion is a functional analog sulfate that during the process of cellular respiration can be transported into the bacteria, resulting in the deprivation of sulfur reducing compounds (Patidar \& Tare, 2005; Barajas et al., 2011). Thus, this acts as an ion specific metabolic inhibitor that limits 
sulfate reduction and is toxic to these microorganisms.

Some studies have investigated the minimum concentration of molybdate necessary for growth inhibition in groups of sulfate-reducing bacteria (Newport \& Nedwell, 1988; Patidar \& Tare, 2005; Predicala et al., 2008; Rincón et al., 2008; Biswas et al., 2009; Barajas et al., 2011). Newport and Nedwell (1998) found that 0.04 to $0.2 \mathrm{mM}$ (6.4 to $32.0 \mathrm{mg} \mathrm{L}^{-1}$ ) molybdate was sufficient to stop the growth of pure cultures of SRB in a culture medium low in sulfate $5 \mathrm{mM}\left(480 \mathrm{mg} \mathrm{L}^{-1}\right)$. In an analogous study, Biswas et al. (2009) studied the inhibition of sulfate-reducing bacteria and the growth of pure cultures by applying molybdate in an environment of $20 \mathrm{mM}\left(1920 \mathrm{mg} \mathrm{L}^{-1}\right)$ sulfate. The authors found that concentrations above $2 \mathrm{mM}\left(320 \mathrm{mg} \mathrm{L}^{-1}\right)$ molybdate were sufficient to eliminate completely the production of $\mathrm{H}_{2} \mathrm{~S}$, and concluded that the effectiveness of inhibition should occur whenever the molar ratio molybdate / sulfate is greater than 1:10. Rincón et al. (2008) evaluated the use of molybdate on the growth kinetics and bacterial sulfate reduction and investigated its effect on reducing corrosion rates in a medium with 12.5 $\mathrm{mM}$ (1200 $\left.\mathrm{mg} \mathrm{L}^{-1}\right)$ sulfate. Batch experiments performed to determine the minimum inhibitory concentration indicated that $5 \mathrm{mM}\left(800 \mathrm{mg} \mathrm{L}^{-1}\right)$ molybdate was sufficient to reduce the number of free bacteria to undetectable levels and for the complete elimination of the generation of $\mathrm{H}_{2} \mathrm{~S}$. The authors also concluded that the application of molybdate was effective in controlling biocorrosion. Predicala et al. (2008) studied the control of $\mathrm{H}_{2} \mathrm{~S}$ emissions from swine manure using sodium molybdate. The tests were conducted in a batch mode by applying molybdate in a medium with fresh manure slurry and populations of active sulfate-reducing bacteria. The gas samples were collected and analyzed to determine the concentrations of hydrogen sulfide. The authors observed that reducing the $\mathrm{H}_{2} \mathrm{~S}$ concentration in the gas phase was related to the concentration of molybdate present in the medium. The application of $2 \mathrm{mM}$ (320 mg L${ }^{-1}$ ) of molybdate was sufficient to reduce the concentration of $\mathrm{H}_{2} \mathrm{~S}$ in the gas phase for 40 days to negligible levels.

Although the role of molybdenum in the synthesis of enzymes is well known, further studies need to investigate the effect of molybdate as an inhibitor of the activity of specific groups of sulfatereducing bacteria. The objective of this study is to evaluate the efficiency of implementing molybdate in the control of the activity of SRB, isolated from the produced water from oil wells in the Reconcavo Basin, Brazil.

\section{MATERIALS AND METHODS}

The effectiveness of molybdate as an inhibitor of the activity of SRB was investigated from its application in a medium containing a microbial consortium enriched from produced water samples collected in an oil field of the Reconcavo basin, Brazil. This consortium was dominated by Desulfovibrio vulgaris (Bernardez et al., 2007).

The experiments were divided into two parts: first, the study of the kinetics of sulfate reduction inhibition, and, second, determining the minimum inhibitory concentration of molybdate. The molybdate concentrations evaluated were selected from literature and correspond to mole fractions of sulfate available in the medium.

\subsection{Microbial culture and medium}

A volume of $100 \mu \mathrm{L}$ of mixed culture of sulfatereducing bacteria (SRB), taken from the produced water from an oil field, was inoculated and enriched in a modified Postgate medium inside an anaerobic chamber (Bactron VI, Shellab, Sheldon Manufacturing Inc.) at $38^{\circ} \mathrm{C}$. The anaerobic mixed gas used was $5 \%$ hydrogen, $5 \%$ carbon dioxide, and $90 \%$ nitrogen.

The modified Postgate medium semi solid, in which sodium lactate was used as a main carbon source and electron donor, contained (per liter): agar $2.0 \mathrm{~g}, \mathrm{KH}_{2} \mathrm{PO}_{4} 0.5 \mathrm{~g}, \mathrm{NH}_{4} \mathrm{Cl} 1.0 \mathrm{~g}, \mathrm{Na}_{2} \mathrm{SO}_{4} 1.0 \mathrm{~g}$, $\mathrm{CaCl}_{2} 1.0 \mathrm{~g}, \mathrm{MgCl}_{2} .6 \mathrm{H}_{2} \mathrm{O} 1.83 \mathrm{~g}$, yeast extract $1.0 \mathrm{~g}$, ascorbic acid $0.1 \mathrm{~g}$, sodium thioglycollate $0.013 \mathrm{~g}$, sodium citrate $6.38 \mathrm{~g}$, sodium lactate $2.21 \mathrm{~g}, \mathrm{NaCl}$ $15 \mathrm{~g}$, resazurin $2.0 \mathrm{~mL}\left(0.025 \% \mathrm{p} \mathrm{v}^{-1}\right)$, and $\mathrm{FeSO}_{4} .7 \mathrm{H}_{2} \mathrm{O} \quad 0.5 \mathrm{~g}$. All the components were dissolved in deionized water and the $\mathrm{pH}$ was adjusted to 7.5 to 8.0 using $\mathrm{HCl}$ or $\mathrm{NaOH}$. After this, the solution was homogenized by agitation and, later, sterilized at $121^{\circ} \mathrm{C}$ for 30 minutes. This supports the growth of a wide spectrum of SRB, stimulating microbial diversity. 


\subsection{Kinetic inhibition tests}

The kinetic inhibition of sulfate reduction was investigated in a batch mode in sealed $250 \mathrm{~mL}$ glass bottles. For these experiments, an equal amount of $200 \mathrm{~mL}$ of the previously autoclaved medium was put in each bottle, without agar, and $2.0 \mathrm{~mL}$ of inoculum was added. Then, the bottles were put inside an anaerobic chamber and mixed continuously in a mechanical shaker at 120 RPM at $38^{\circ} \mathrm{C}$. At certain time intervals, one bottle was selected, aliquots were withdrawn and used for the chemical analysis, and, following, the bottle content was excluded. In the experiment, $\mathrm{Na}_{2} \mathrm{SO}_{4}$ $(1.18 \mathrm{~g})$ and $\mathrm{FeSO}_{4} .7 \mathrm{H}_{2} \mathrm{O}(0.59 \mathrm{~g})$ were enhanced proportionately in the culture medium to reach a

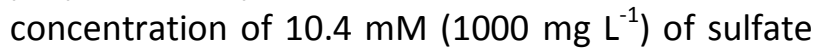
ion. Concentrations were selected from the literature and corresponded to a mole fractions of sulfate less than or equal to one. In Table 1, the concentrations of molybdate and molar ratios of molybdate/sulfate evaluated are presented.

\subsection{Minimum inhibition concentration of molybdate test}

The experiments carried out to investigate the kinetics of inhibition were performed using the modified Postgate medium, in which sodium lactate was used as the main carbon source and electron donor. It contained (per liter): $\mathrm{KH}_{2} \mathrm{PO}_{4} 0.5$ g, $\mathrm{NH}_{4} \mathrm{Cl} 1.0 \mathrm{~g}, \mathrm{Na}_{2} \mathrm{SO}_{4} 1.0 \mathrm{~g}, \mathrm{CaCl}_{2} 0.6 \mathrm{~g}$, yeast extract $1.0 \mathrm{~g}$, ascorbic acid $0.1 \mathrm{~g}$, sodium thioglycollate $0.013 \mathrm{~g}$, sodium citrate $0.3 \mathrm{~g}$, sodium lactate $6.78 \mathrm{~g}, \mathrm{NaCl} 15 \mathrm{~g}, \mathrm{FeSO}_{4} .7 \mathrm{H}_{2} \mathrm{O} 0.02 \mathrm{~g}$, and $\mathrm{MgSO}_{4} .7 \mathrm{H}_{2} \mathrm{O} 0.09 \mathrm{~g}$. All the components were dissolved in deionized water and the $\mathrm{pH}$ was adjusted to 7.0 using $\mathrm{HCl}$ or $\mathrm{NaOH}$. After this, the solution was homogenized by agitation and, later, sterilized at $121^{\circ} \mathrm{C}$ for 30 minutes.

The medium modified Postgate $C$ contains iron which is an important micronutrient used by SRB. However, the iron may act indirectly as an indicator of activity because the ferrous ion in the presence of sulfides can form iron sulfides ( $\mathrm{FeS}, \mathrm{Fe}_{2} \mathrm{~S}$ ), which precipitate as fine particles with dark coloring. The formation of these materials is an indicator of the activity of SRB and it was used in the tests as a criterion for assessing the activity of bacteria in the medium. To ensure that the carbon source was not the limiting agent for bacterial growth, the culture medium was prepared with an excess of lactate, $45 \%$ higher than the stoichiometric equation. In the
Table 1. Concentrations of molybdate and molar ratio molybdate/sulfate. Initial concentration of sulfate $10.4 \mathrm{mM}$ (1000 $\left.\mathrm{mg} \mathrm{L}^{-1}\right)$.

\begin{tabular}{cc}
\hline Molybdate $(\mathrm{mM})$ & $\mathrm{MoO}_{4}{ }^{2-} / \mathrm{SO}_{4}{ }^{2-}$ \\
\hline 2.0 & 0.20 \\
1.0 & 0.10 \\
0.5 & 0.05 \\
\hline
\end{tabular}

Table 2. Concentrations of molybdate and molar ratio molybdate/sulfate. Initial concentration of

\begin{tabular}{cc}
\multicolumn{2}{c}{ sulfate $20.8 \mathrm{mM}\left(2000 \mathrm{mg} \mathrm{L}^{-1}\right)}$. \\
\hline Molybdate $(\mathrm{mM})$ & $\mathrm{MoO}_{4}{ }^{2-} / \mathrm{SO}_{4}{ }^{2-}$ \\
\hline 20.80 & 1.0000 \\
10.40 & 0.5000 \\
5.20 & 0.2500 \\
4.20 & 0.2000 \\
2.10 & 0.1000 \\
1.00 & 0.0500 \\
0.50 & 0.0250 \\
0.20 & 0.0100 \\
0.08 & 0.0040 \\
0.04 & 0.0020 \\
0.03 & 0.0015 \\
0.02 & 0.0010 \\
\hline
\end{tabular}

experiment, the amount of $\mathrm{Na}_{2} \mathrm{SO}_{4}(2.36 \mathrm{~g})$ and $\mathrm{FeSO}_{4} .7 \mathrm{H}_{2} \mathrm{O}(1.18 \mathrm{~g})$ were enhanced proportionately in the culture medium to reach a concentration of $20.8 \mathrm{mM}\left(2000 \mathrm{mg} \mathrm{L}^{-1}\right)$ of sulfate ion.

The tests were performed in batch mode in sealed $100 \mathrm{~mL}$ glass bottles so that each concentration was assessed in duplicate. In each vial of $60 \mathrm{~mL}, 600 \mu \mathrm{L}$ of inoculum were added as inhibitor. Then, the bottles were mixed continuously in a mechanical shaker at 180 RPM at $38^{\circ} \mathrm{C}$ in anaerobic conditions. Samples were taken with simultaneous removal of two of the four bottles from the incubator 72 and 168 hours after the start of the test. The bottles were selected and analyzed, then, the bottles contents were excluded. In each test, four bottles were used as control without the addition of the inhibitor. These bottles were also sampled at 72 and 168 hours after the start of the test.

Tests with high concentrations of molybdate were performed with the culture medium containing 0.2 to $20 \mathrm{mM} \mathrm{(32} \mathrm{to} 3200 \mathrm{mgL}^{-1}$ ) of the inhibitor while assays with reduced concentrations of molybdate were performed with a culture medium containing 0.02 to $0.2 \mathrm{mM}$ ( 3.2 to $32 \mathrm{mgL}^{-1}$ ) of the inhibitor. In Table 2, the concentrations of 
molybdate and molar ratios of molybdate/sulfate evaluated are presented.

\subsection{Sulfate concentration}

The sulfate concentrations were measured by a turbidimetric method (Kolmert et al., 2000). This method is based on the precipitation of sulfate ions as barium sulfate. The samples, before the analysis of the sulfate content, were treated with an excess of zinc acetate dihydrate crystals to precipitate the dissolved sulfide as zinc sulfide. Fixation of sulfide prevented the oxidation to sulfate. Using $1.5 \mathrm{~mL}$ microcentrifuged tubes, $1.0 \mathrm{~mL}$ culture samples were stirred for five seconds with approximately $0.01 \mathrm{~g}$ of zinc acetate. The mixture was, then, centrifuged for ten minutes at 6000 RPM and at $4^{\circ} \mathrm{C}$. Following, $50 \mu \mathrm{L}$ of the supernatant was mixed with $950 \mu \mathrm{L}$ of the conditioning fluid in a fresh microcentrifuge tube and stirred for five seconds. Approximately $0.01 \mathrm{~g}$ of crushed barium chloride dihydrate crystals was added to the mixture, which was stirred for 15 seconds and the relative absorbance was read immediately at $420 \mathrm{~nm}$ using a UV/Visible spectrophotometer. The calibration standards were prepared using sodium sulfate and deionized water.

\subsection{Sulfide concentration}

The sulfide content of the samples was also measured using a turbidmetric method (CordRuwisch, 1985). The measurement had to be done immediately after sampling to prevent its oxidation and volatilization. When copper sulfate is added to a solution containing sulfide, copper sulfide precipitates. The assay is based on this precipitation of colloid copper sulfide, because the absorbance of the resulting mixture can be measured at $480 \mathrm{~nm}$ and it is proportional to the sulfide concentration. Using $1.5 \mathrm{~mL}$ microcentrifuge tubes, $50 \mu \mathrm{L}$ of the culture samples were mixed with $950 \mu \mathrm{L}$ copper solution $(5.0 \mathrm{mM}$ $\mathrm{CuSO}_{4} .5 \mathrm{H}_{2} \mathrm{O}$ and $50 \mathrm{mM} \mathrm{HCl}$ ) and, then, stirred for five seconds. After, the relative absorbance was measured at $480 \mathrm{~nm}$ using the spectrophotometer Spectro UV-Vis RS Model UV-2500.

\subsection{Solution $\mathrm{pH}$ and oxidation-reduction potential}

For the $\mathrm{pH}$ measurements, a Thermo Orion PerpHecT Meter (Model 330) was used. The pH meter was calibrated using buffer solutions $(\mathrm{pH}$ of 4 and 7) regularly. Redox potential differences, $\Delta E$, were measured ex-situ using an ORP electrode with an internal $\mathrm{Ag} / \mathrm{AgCl}$ reference electrode from Cole-Parmer. The measurements were calibrated with ORP standard solutions (Analion) of 470 and $220 \mathrm{mV}$ at $20^{\circ} \mathrm{C}$. The $\mathrm{pH}$ values and redox potential diferrence were measured before and after the sample collection.

\section{RESULTS AND DISCUSSION}

\subsection{Kinetic inhibition tests}

Figures $1 \mathrm{a}$ and $\mathrm{b}$ show the results of the sulfate consumption and sulfide production time evolution for the initial solution with a sulfate content of 10.4 $\mathrm{mM}\left(1000 \mathrm{mg} \mathrm{L}^{-1}\right)$. The sulfate present in the medium was consumed rapidly during the first 216 hours, and remained stable after this time. The sulfate conversion $\left(\alpha=\left(1-\left[\mathrm{SO}_{4}{ }^{2-}\right] /\left[\mathrm{SO}_{4}{ }^{2-}\right]_{0}\right) \times 100\right)$ found for this time was $78 \%$. The maximum sulfide production of $6.9 \mathrm{mM}\left(220 \mathrm{mg} \mathrm{L}^{-1}\right)$ was reached within 50 hours after the start of the trial and remained nearly constant until the end of the experiment. The kinetic curves of sulfate reduction and sulfide production in the culture medium with $0.5,1.0$, and $2.0 \mathrm{mM}\left(80,160\right.$ and $\left.320 \mathrm{mg} \mathrm{L}^{-1}\right)$ of molybdate are also shown in Figures $1 \mathrm{a}$ and $1 \mathrm{~b}$. Regardless of the molybdate concentration in the culture medium, the sulfate consumption was inhibited for a period equal to 360 hours (Figure 1a). For these media, the conversion of sulfate to sulfide for 216 hours was 23, 27, and 42\%, respectively. Although the sulfate conversion was relatively high, the maximum concentration of sulfide in the same period was approximately 1.6 $\mathrm{mM}\left(52 \mathrm{mg} \mathrm{L}^{-1}\right.$ ) (Figure 1b). The difference between the reduced amount of sulfate and the sulfide produced can be explained by the formation of sulfides of iron and molybdenum present in the medium. The bottles with $0.5 \mathrm{mM}\left(80 \mathrm{mg} \mathrm{L}^{-1}\right)$ molybdate collected at 144,312 , and 360 hours presented a reddish brown color.

Figure 1c shows the solution oxidationreduction potential time evolution of the control and the bottles with molybdate. The redox potential curves have analogous shapes to the sulfate conversion curves (Figure 1a) with a rapid reduction at the beginning and thereafter a slow 


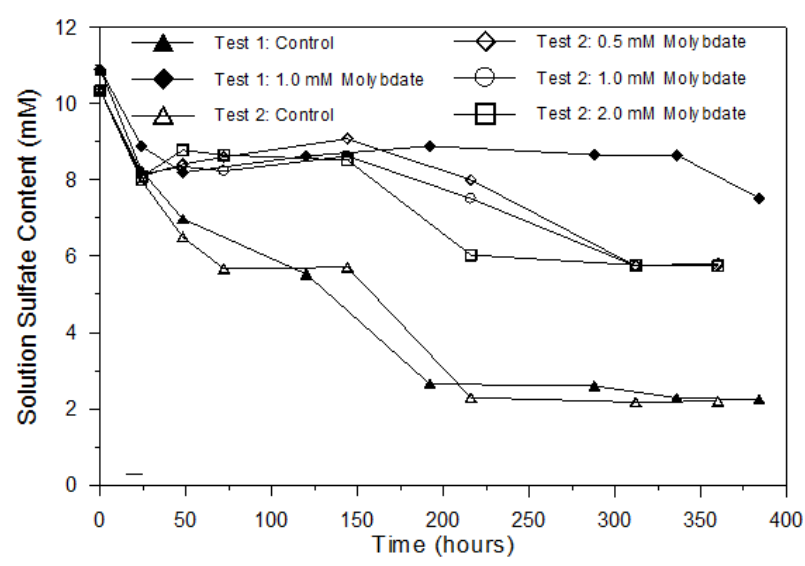

(a)

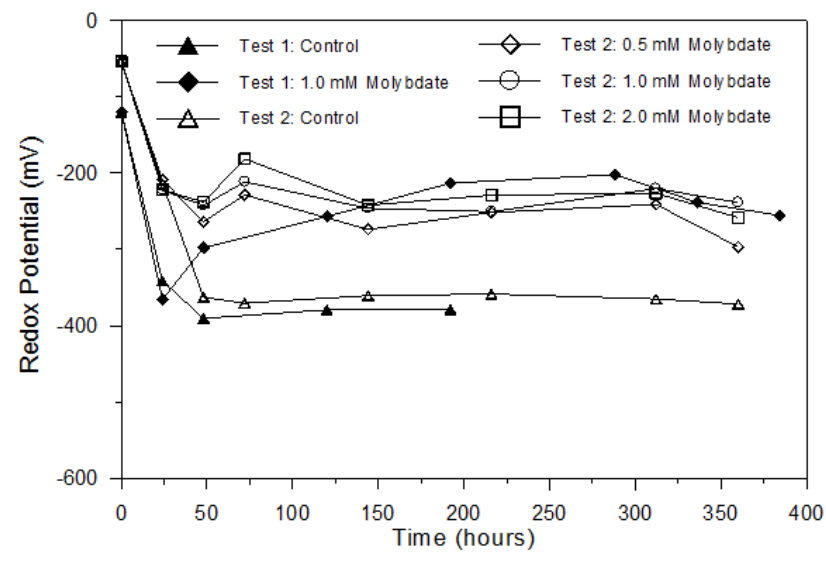

(c)

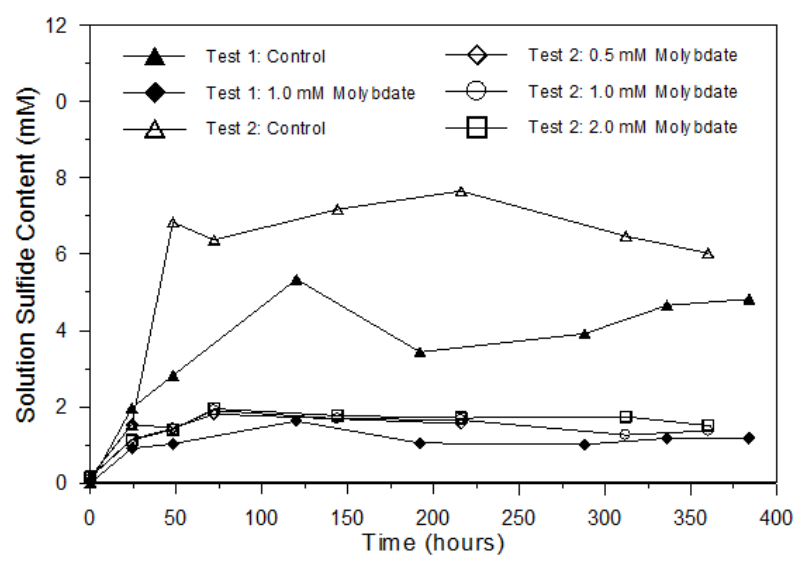

(b)

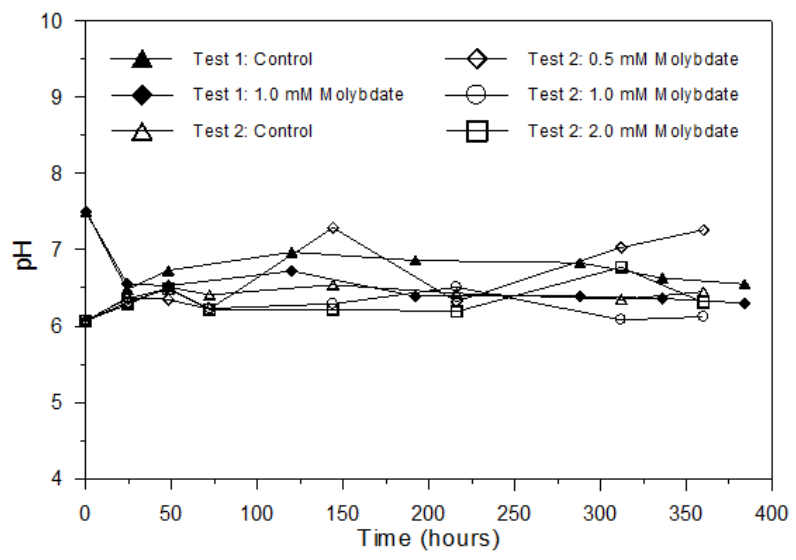

(d)

Figure 1. Kinetic tests for $\left[\mathrm{SO}_{4}{ }^{2-}\right]_{0}=10.4 \mathrm{mM}\left(1000 \mathrm{mg} \mathrm{L}^{-1}\right)$ with or without molybdate: a) Sulfate solution content, b) sulfide solution content, c) solution oxidation-reduction potential, d) $\mathrm{pH}$ solution.

reduction. However, the redox potential of the medium without molybdate reaches stability at $365 \mathrm{mV}$ while the stability of the redox potential in the medium containing different concentrations of molybdate occurs at $-245 \mathrm{mV}$. During the experiment the $\mathrm{pH}$ of the medium remained nearly constant at 6.5 (Figure $1 \mathrm{~d}$ ).

The results obtained in the kinetic experiments show that the sulfate reduction occurs primarily during the first hours of the start of the test. From this information, optimized tests to investigate the minimum inhibition concentration of molybdate were performed. It was assumed that a period of 168 hours is enough to observe the effectiveness of the inhibition.

\subsection{Minimum inhibition concentration of molybdate test}

Figure 2 shows the bottles with the inoculum after 168 hours and a molybdate concentration range from 0.2 to $2.0 \mathrm{mM}$ ( 32 to $3200 \mathrm{mg} \mathrm{L}^{-1}$ ). Note that in the control bottle, without the presence of molybdate, the medium appeared dark indicating the activity of SRB by precipitating iron sulfide. The absence of black precipitate in the medium in the bottle with molybdate indicates inhibition of bacterial activity during the evaluated period, which occurred in all bottles.

Figure 3a shows the inoculum bottles after 72 hours for a concentration range of molybdate from 0.02 to $0.20 \mathrm{mM}$ (3.2 to $32 \mathrm{mg} \mathrm{L}^{-1}$ ). In this case, it can be seen that only the control bottles showed a black precipitate of the medium. Figure $3 b$ shows 


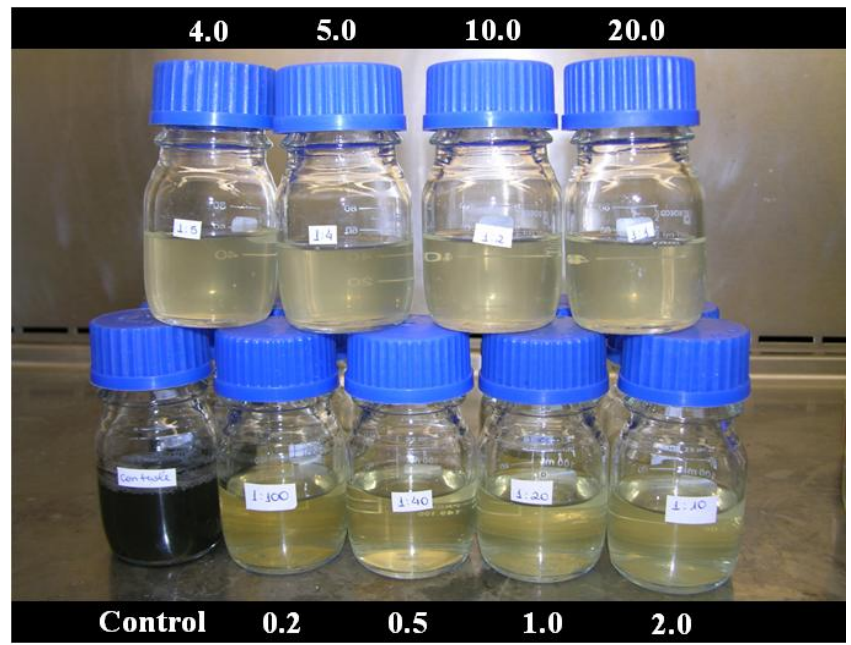

Figure 2. Tests of inhibition of microbiological reduction of sulfate in 168 hours with the addition of 0.2 to $20 \mathrm{mM}$ (32 to $3200 \mathrm{mg} \mathrm{L}^{-1}$ ) of molybdate.

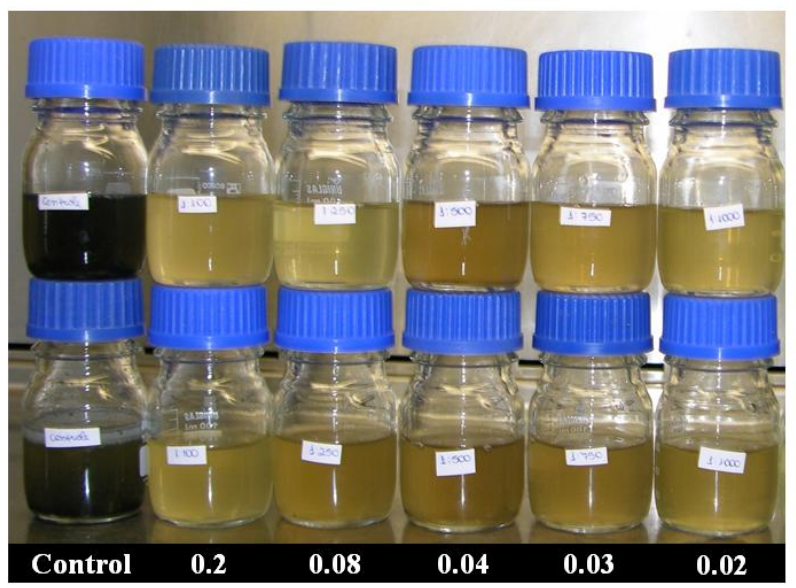

(a)

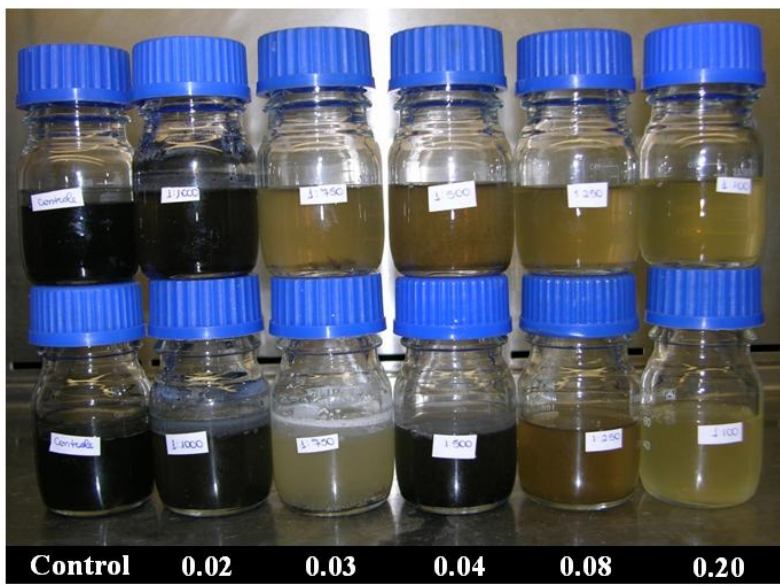

(b)

Figure 3. Tests of inhibition of microbiological reduction of sulfate with 0.02 to $0.2 \mathrm{mM}\left(3.2\right.$ to $\left.32 \mathrm{mg} \mathrm{L}^{-1}\right)$ of molybdate, with repetition and for contact times of: a) 72 hours b) 168 hours.

the inoculum bottles after 168 hours for the same range of molybdate concentrations. The control bottle remained dark, while the one containing with $0.02 \mathrm{mM}\left(3.2 \mathrm{mg} \mathrm{L}^{-1}\right)$ of molybdate became brown. Bottles with $0.03 \mathrm{mM}\left(4.8 \mathrm{mg} \mathrm{L}^{-1}\right)$ of molybdate showed the formation of a dark precipitate. The same behavior was observed in one of the bottles with $0.04 \mathrm{mM}\left(6.4 \mathrm{mg} \mathrm{L}^{-1}\right)$ molybdate, while another showed a complete browning of the medium. The bottles with 0.08 and $0.2 \mathrm{mM}\left(12.8\right.$ and $\left.32 \mathrm{mg} \mathrm{L}^{-1}\right)$ molybdate showed no significant change in color.

Figure 4 shows the $\mathrm{pH}$ values as a function of the concentration of molybdate. Despite the variability of the measured values (the average relative deviation of $\mathrm{pH}$ measurements $\left(\sigma_{x} / \bar{x}\right)$ was $2.0 \%$ in 72 hours and $3.1 \%$ in 168 hours) one can observe that, for lower concentrations, the $\mathrm{pH}$ of the medium was reduced and that, for higher concentrations, the $\mathrm{pH}$ remained close to its initial value. The activity of SRB tends to lower the $\mathrm{pH}$ due to the generation of acid and the redox potential of the solution due to oxidation of the carbon source.

The SRB causes a reduction in the redox potential of the solution, which is used as an indicator of the activity of these microorganisms. 


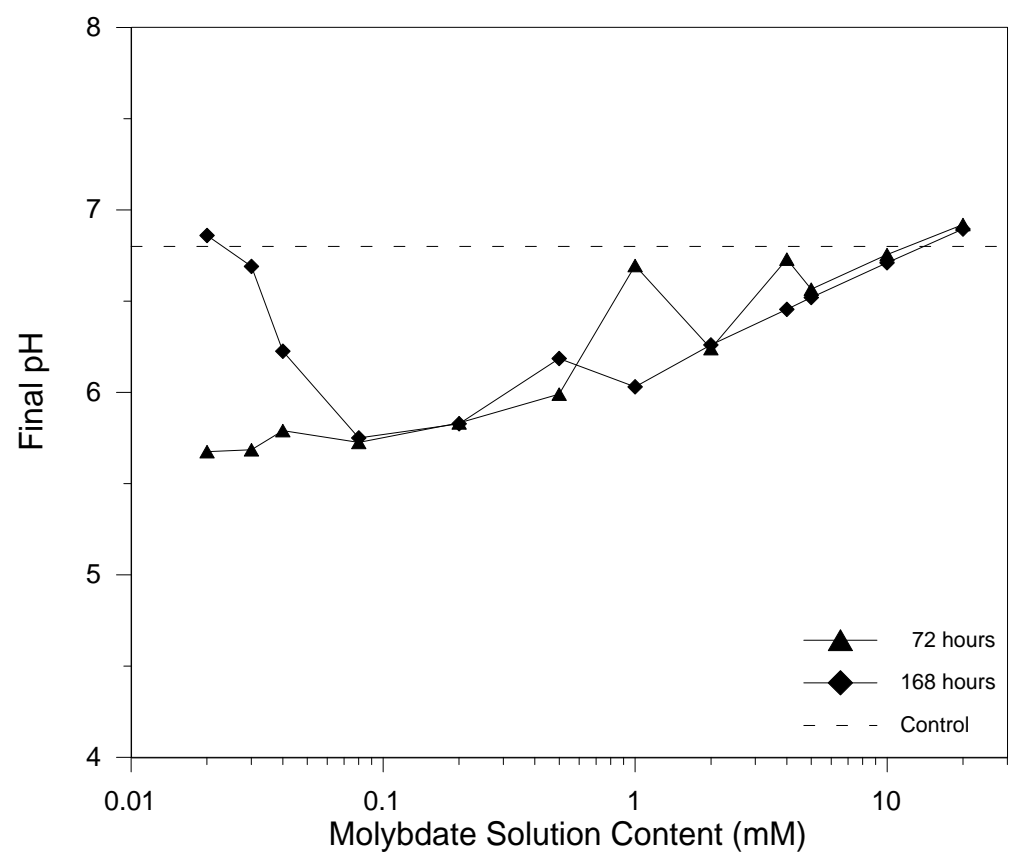

Figure 4. Effect of inhibiting microbial reduction of sulfate by molybdate on the $\mathrm{pH}$ of the solution.

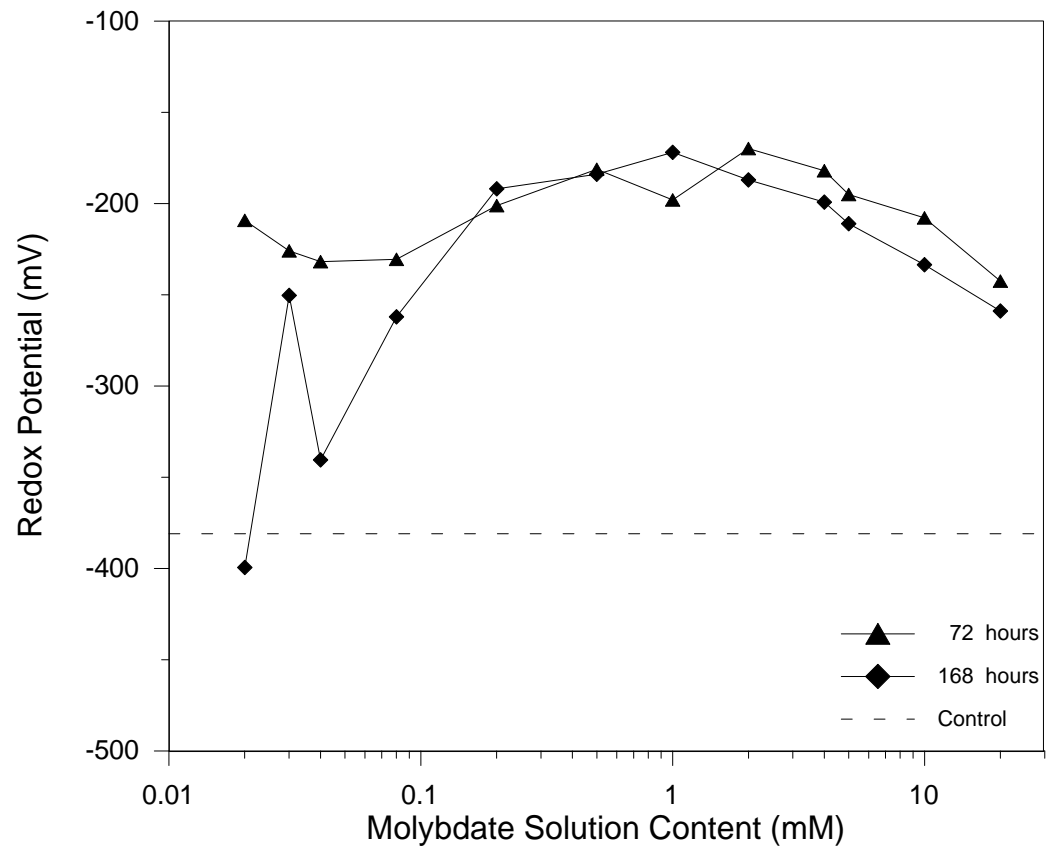

Figure 5. Effect of inhibiting microbial reduction of sulfate by molybdate on the redox potential solution.

Figure 5 shows the redox potential as a function of the concentration of molybdate. The average relative deviation of the redox potential measurements was $3.4 \%$ in 72 hours and $5.61 \%$ in 168 hours. The redox potential value for the tests without molybdate (dash line) was about $-350 \mathrm{mV}$; this value was maintained until the end of the experiment confirming the microbial activity during the test. The redox potential of the bottles with molybdate were higher than $-250 \mathrm{mV}$. The results show that for a period shorter than 72 hours a molybdate concentration equal or higher than 0.02 $\mathrm{mM}\left(3.2 \mathrm{mg} \mathrm{L}^{-1}\right)$ is enough to inhibit the SRB. For a longer time, the inhibition is only achieved with a concentration equal to or higher than $0.08 \mathrm{mM}$ (12.8 $\mathrm{mg} \mathrm{L}^{-1}$ ) (Figure $3 b$ ). 


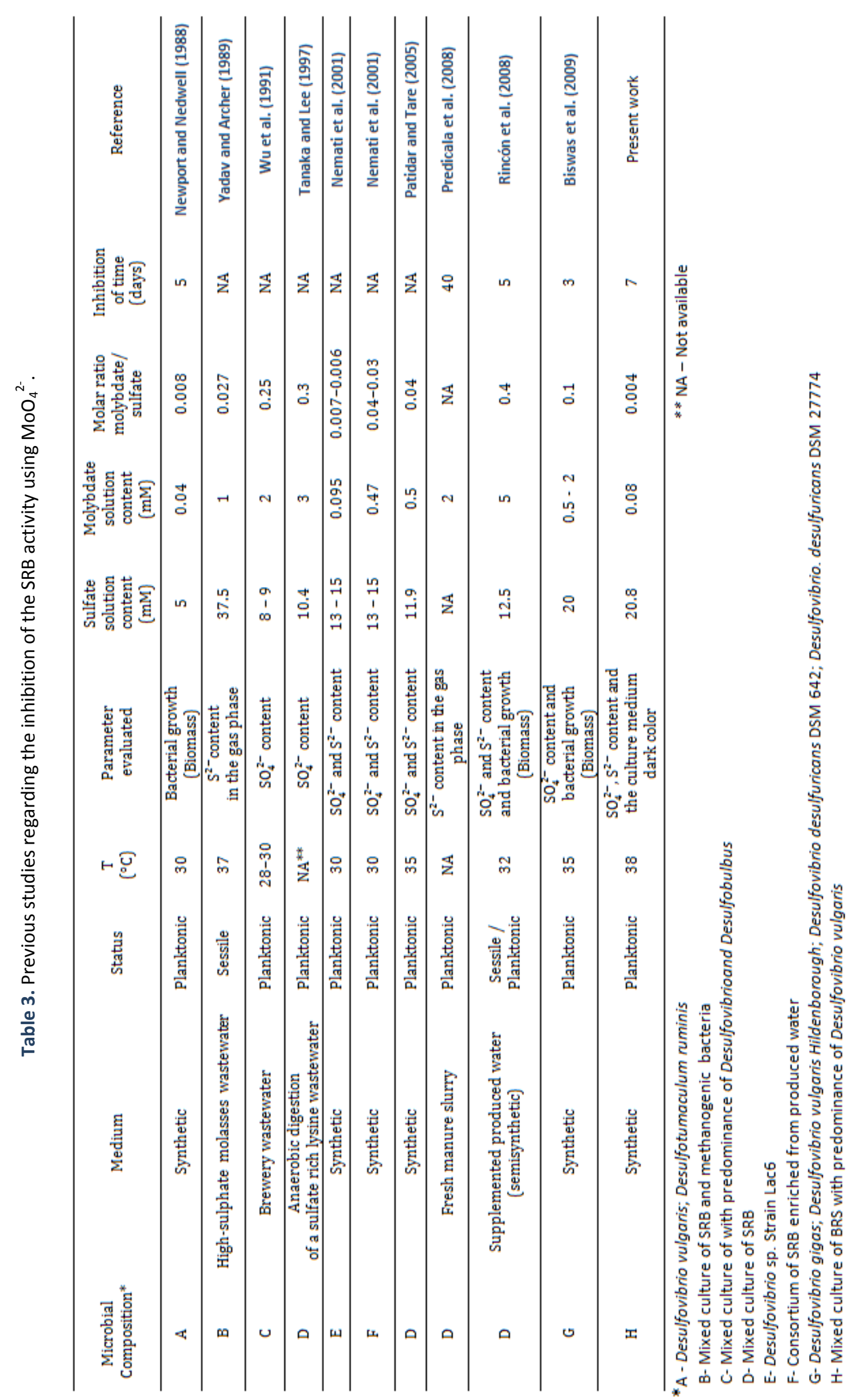


Table 3 summarizes the experimental conditions and the results of the molybdate SRB inhibition studies, including those in the present work. It is noticeable that in cases of pure cultures of SRB, which are less resistant to environmental changes than mixed cultures, low values of molybdate solution content and molar ratio molybdate/sulfate were used. For instance, Newport and Nedwell (1988) and Nemati et al. (2001) used molecular ratios of 0.006 to 0.008 to inhibit the activity of SRB and Biswas et al. (2009) used 0.1. The inhibition time of the pure culture of SRB by molybdate treatment is about 3 to 5 days. For mixed cultures Rincón et al. (2008) found that a high molybdate solution content is necessary for SRB inhibition. The molar ratio molybdate/sulfate was 0.4 and the inhibition time was 5 days. In the present study it was found that the lowest molar molybdate/sulfate ratio that exhibits inhibition for a mixed culture is 0.004 and the inhibition time was 7 days.

Another important aspect that should be noted is the effect of temperature on the effectiveness of microbial activity inhibition. Moosa et al. (2005) and Oyekola et al. (2010) showed that the reduction kinetics of sulfate and sulfide production is affected by increasing the temperature of the medium, increasing sulfate reduction rate and sulfide production. Therefore, in tests performed at higher temperature conditions, the SRB have a higher sulfate reduction capacity and sulfide production, and this shows the effectiveness of the results obtained in this study, conducted in high temperature conditions $\left(38^{\circ} \mathrm{C}\right)$.

The results presented in this study are the most promising found for the use of molybdate inhibition of SRB from oil fields, especially due to the low concentrations of molybdate found and the long inhibition time. Simulation studies, along with pilot and industrial oil field tests, can be performed using these results to control souring. In this case, the main objective is to maintain the lowest inhibition solution content in the regions of the oil reservoir that have SRB activity, for instance, close to the water injection wells. This will be the object of future studies in this ongoing project.

Despite the fact that the microbial sulfide generation inhibition in this study was performed in batch experiments instead of continuous packed bed upflow reactors, the results are consistent with those presented by Bernardez et al. $(2012,2013)$, which show that the sulfate reduction and the sulfide generation due to the SRB are first order processes for both cases, with and without biofilm formation, respectively. Therefore, the results for the inhibition concentration for the batch experiments presented in this study are a strong indication of the inhibition concentration in other scale experiments, such as in fixed bed reactors or in oil fields.

\section{CONCLUSIONS}

This study investigated the control of the activity of sulfate-reducing bacteria by using molybdate. Kinetic tests for inhibition of sulfate reduction and short-term tests to determine the minimum inhibitory concentration of molybdate were performed. The indicators of bacterial activity were evaluated for sulfate reduction, sulfide production, blackening of the culture medium due to the formation of iron sulfides, $\mathrm{pH}$, and redox potential. A comparison of the results shows that molybdate is able to inhibit the activity of mixed cultures of sulfate-reducing bacteria in a period equal to 360 hours. The minimum inhibitory concentration found in the case of sulfate-reducing bacteria isolated from oil fields in the Reconcavo Basin, Brazil was with $0.08 \mathrm{mM}$ molybdate $(12.8 \mathrm{mg}$ $\left.\mathrm{L}^{-1}\right)$, the molar ratio molybdate/sulfate equal to 0.004 for a period of $168 \mathrm{~h}$. Although the concentration of molybdate inhibition threshold is close to the values found in the literature, in this case, the smallest molar ratio molybdate/sulfate inhibition was below previously reported values. Furthermore, the efficiency of the inhibition of molybdate indicated by the inhibition time was considerably higher than that reported in the literature.

\section{ACKNOWLEDGEMENTS}

This work was supported by the CNPq, grants 475810/2008-2, 476344/2009-5, 550537/2009-0, 309707/2010-2 and 480181/2011-0, FINEP/ PETROBRAS/ANP (Project numbers: FINEP 0.1.05.0974.00/ PETROBRAS 0050.001843106.4/ SAP, contract number 4600202295). E.B. de Jesus thanks the CNPq for a graduate scholarship for this project. L.A. Bernardez works under a grant of the Programa Nacional de Pós-Doutorado (CAPES/PNPD). 


\section{REFERENCES}

Barajas, E.A.; Pérez, C.D.; Díaz, M.I.R.; Rosas, H.R.; Cervantes, C. Bacterial transport of sulfate, molybdate, and related oxyanions. Biometals, v. 24, p. 687-707, 2011.

http://dx.doi.org/10.1007/s10534-011-9421-x

Bernardez, L.A.; de Andrade Lima, L.R.P.; Almeida, P.F. Corrosion of stainless steels exposed to seawater containing sulfate-reducing bacteria. Brazilian Journal of Petroleum and Gas, v. 1, p. 5158, 2007.

Bernardez, L.A.; de Andrade Lima, L.R.P.; Ramos, C.L.; Almeida, P.F. A kinetic analysis of microbial sulfate reduction in an upflow packedbed anaerobic bioreactor. Mine Water and the Environment, v. 26, p. 62-68, 2012.

http://dx.doi.org/10.1007/s10230-012-0170-z

Bernardez, L.A.; de Andrade Lima, L.R.P.; de Jesus, E.B.; Ramos, C.L.S.; Almeida, P.F. A kinetic study on bacterial sulfate reduction. Bioprocess and Biosystems Engineering, v. 36, p. 1861-1869, 2013. http://dx.doi.org/10.1007/s00449-013-0960-0

Birkeland, N.K. Sulfate-reducing bacteria and archea. In: Ollivier, B.; Magot, M. Petroleum Microbiology. Washington: ASM Press, p. 35-54, 2005. http://dx.doi.org/10.1128/9781555817589.ch3

Biswas, K.C.; Woodards, N.A.; Xu, H.; Barton, L.L. Reduction of molybdate by sulfate-reducing bacteria. Biometals, v. 22, p. 131-139, 2009. http://dx.doi.org/10.1007/s10534-008-9198-8

Chang, Y.J.; Chang, Y.T.; Chen, H.I. A method for controlling hydrogen sulfide inwater by adding solid phase oxygen. Bioresource Technology, v. 98, p. 478-483, 2007.

http://dx.doi.org/10.1016/i.biortech.2005.11.031

Cord-Ruwisch, R. A quick method for the determination of dissolved and precipitated sulfides in cultures of sulfate-reducing bacteria. Journal of Microbiological Methods, v. 4, p. 33-36, 1985. http://dx.doi.org/10.1016/0167-7012(85)90005-3

Davidova, I.; Hicks, M.S.; Fedorak, P.M.; Suflita, J.M. The influence of nitrate on microbial processes in oil industry production waters. Journal of Industrial Microbiology and Biotechnology, v. 27, p. 80-86, 2001.

http://dx.doi.org/10.1038/sj.jim.7000166
Greene, E.A.; Hubert, C.; Nemati, N.; Jenneman, G.E.; Voordouw, G. Nitrite reductase activity of sulphate-reducing bacteria prevents their inhibition by nitrate-reducing, sulphide-oxidizing bacteria. Environmental Microbiology, v. 5, p. 607-624, 2003.

http://dx.doi.org/10.1046/j.1462-2920.2003.00446.x

Hubert, C.; Nemati, M.; Jenneman, G.; Voordouw, G. Corrosion risk associated with microbial souring control using nitrate or nitrite. Environmental Biotechnology, v. 68, p. 272-282, 2005. http://dx.doi.org/10.1007/s00253-005-1897-2

Jenneman, G.E.; McInerney, M.J.; Knapp, R.M. Effect of nitrate on biogenic sulfide production. Applied and Environmental Microbiology, v.51, p. 1205-1211, 1986.

Jordan, L. C.; Walsh, J. M. Selection of an active souring management solution for a Gulf of Mexico waterflood, Proceedings of the 2004 SPE Corrosion, New Orleans, Louisiana, p. 1-11, 2004.

Kaster, K.M.; Grigoriyan, A.; Jenneman, G.; Voordouw, G. Effect of nitrate and nitrite on sulfide production by two thermophilic, sulfate-reducing enrichments from an oil field in the North Sea. Applied Microbiology and Biotechnology, v. 75, p. 195-203, 2007. http://dx.doi.org/10.1007/s00253-006$\underline{0796-5}$

Kolmert, Å.; Wikström, P.; Hallberg, K.B. A fast and simple turbidimetric method for the determination of sulfate in sulfate-reducing bacterial cultures. Journal of Microbiological Methods, v. 41, p. 179-184, 2000.

http://dx.doi.org/10.1016/S0167-7012(00)00154-8

Larsen, J.; Rod, M.H.; Zwolle, S. Prevention of reservoir souring in the Halfdan field by nitrate injection, Proceedings of the 2004 SPE Corrosion, New Orleans, Louisiana, p.1-18, 2004.

Larsen, J.; Sanders, P.F.; Talbot, R.E. Experience with use of tetrakishydroxymethylphosphonium sulfate (THPS) for the control of downhole hydrogen sulfide, Proceedings of the 2000 SPE Corrosion, Orlando, Florida, p. 1-18, 2000.

Maxwell, S.; Mutch, K.; Hellings, G.; Badalek, P.; Charlton, P. In-field biocide optimization for magnus water injection system, Proceedings of the 2002 SPE Corrosion, Denver, Colorado, p. 1-12, 2002. 
Moosa, S., Nemati, M., Harrison, S. T. L. A kinetic study on anaerobic reduction of sulphate, part II: incorporation of temperature effects in the kinetic model. Chemical Engineering Science, v. 60, p. 3517-3524, 2005.

http://dx.doi.org/10.1016/i.ces.2004.11.036

Myhr, S.; Lilleb $\varnothing$, B.; Sunde, E.; Beeder, J.; Torsvik, T. Inhibition of microbial $\mathrm{H}_{2} \mathrm{~S}$ production in an oil reservoir model column by nitrate injection. Applied Microbiology and Biotechnology, v. 58, p. 400-408, 2002. http://dx.doi.org/10.1007/s00253-001$\underline{0881-8}$

Nemati, M.; Mazutinec, T.J.; Jenneman, G.E.; Voordouw, G. Control of biogenic $\mathrm{H}_{2} \mathrm{~S}$ production with nitrite and molybdate. Journal of Industrial Microbiology and Biotechnology, v. 26, p. 350-355, 2001. http://dx.doi.org/10.1038/sj.jim.7000142

Newport, P.J.; Nedwell, D.B. The mechanisms of inhibition of Desulfovibrio and Desulfotomaculum species by selenate and molybdate. Journal of Applied Microbiology, v. 65, p.419-423, 1988.

Oyekola, O.O.; Van Hille, R.P.; Harrison, S.T.L. Kinect analysis of biological sulphate reduction using lactate as carbon source and electron donor: Effect of sulphate concentration. Chemical Engineering Science, v. 65, p. 4771-4781, 2010. http://dx.doi.org/10.1016/i.ces.2010.05.014

Patidar, S.K.; Tare, V. Effect of molybdate on methanogenic and sulfidogenic activity of biomass. Bioresource Technology, v. 96, p. 1215-1222, 2005. http://dx.doi.org/10.1016/j.biortech.2004.11.001

Predicala, B.; Nemati, M.; Stade, S.; Laguë, C. Control of $\mathrm{H}_{2} \mathrm{~S}$ emission from swine manure using Na-nitrate and Na-molybdate. Journal of Hazardous Materials, v. 154, p. 300-309, 2008. http://dx.doi.org/10.1016/i.jhazmat.2007.10.026

Rempel, C.L.; Evitts, R.W.; Nemati, M. Dynamics of corrosion rates associated with nitrite or nitrate mediated control of souring under biological conditions simulating an oil reservoir. Journal of Industrial Microbiology and Biotechnology, v. 33, p. 878-886, 2006. http://dx.doi.org/10.1007/s10295$\underline{006-0142-z}$
Rincón, J.R.T.; Gómez, D.M.C.; Caraballo, A.E.S.; Álvarez, J.H.P. Evaluación del molibdato y nitrato sobre bactérias sulfato-reductoras asociadas a procesos de corrosión em sistemas industriales. Revista Argentina Microbiología, v. 40, p. 52-62, 2008.

Rizk, T. Y.; Stott, J. F. D.; Eden, R. D.; Davis, R. A.; Mcelhiney, J. E.; Iorio, C. D.; Hardy, J. A. The effect of desulphated seawater injection on microbiological hydrogen sulphide generation and implication for corrosion control. In: SPE CORROSION 1998, San Diego, Califórnia, Anais... San Diego, p. 1-12, 1988.

Robinson, K.; Ginty, W.; Samuelsen, E.; Lundgaard, T.; Skovhus, T. L. Reservoir souring in a field with sulphate removal: a case study, Proceedings of the 2010 SPE Annual Technical Conference and Exhibition, Florence, Italy, p.1-15, 2010. http://dx.doi.org/10.2118/132697-ms

Sunders, P.F.; Sturman, P.J. Biofouling in the oil industry, In: Ollivier, B.; Magot, M. Petroleum Microbiology. Washington: ASM Press, p. 171-198, 2005. http://dx.doi.org/10.1128/9781555817589.ch9

Tanaka, S.; Lee, Y.H. Control of sulfate reduction by molybdate in anaerobic digestion. Water Science and Technology, v. 36, p. 143-150, 1997. http://dx.doi.org/10.1016/S0273-1223(97)00714-2

Wu, W.M.; Hickey, R.F.; Zeikus, J.G. Characterization of metabolic performance of methanogenic granules treating brewery wastewater: role of sulfate-reducting bacteria. Applied Microbiology and Biotechnology, v. 57, p. 3438-3449, 1991.

Yadav, V. K.; Archer, D. B. Sodium molybdate inhibits sulphate reduction in the anaerobic treatment of high-sulphate molasses wastewater. Applied Microbiology and Biotechnology, v. 31, p. 103-106, 1989. http://dx.doi.org/10.1007/BF00252537 